\title{
Some Observations on the Middle Palaeolithic Culture in North-Western Karnataka with Special Reference to the Site of Kovalli
}

Sony j Mathew* and Sushama G Deo ${ }^{\dagger}$

\begin{abstract}
The Middle Palaeolithic culture has been widely distributed in the Ghataprabha basin, obtained from 113 sites. The majority of the sites are concentrated in the middle and lower reaches of the river Ghataprabha and the assemblage is comprised of scrapers of various types, points, borers and scraper cum borer and borer cum points. The studies conducted at the site Kovalli which lies in the lower reaches of Ghataprabha suggest that the Kovalli assemblage can be categorized as mixture of Middle Palaeolithic and late Middle Palaeolithic. It can be categorized as "advanced" Middle Palaeolithic.
\end{abstract}

Keywords: Assemblage; Middle palaeolithic, Naturally backed knife; Palaeolithic

\section{Introduction}

The Indian sub-continent, particularly the Peninsular India, is recognized as one of the richest areas of Acheulian occupation in the Old World. The first artefacts to be collected and reported from this region were cleavers and hand axes (Foote, 1866, 1916; de Chardin, 1936; de Terra \& Paterson, 1939). The first report of hand axes discovery by Boucher de Perth in 1859 from the terrace gravels

\footnotetext{
* Deccan College Postgraduate and Research Institute, Pune-411006; sonyjmathews@gmail.com

† Deccan College Post-Graduate and Research Institute, Pune-411006
} 
of the Somme valley established Pleistocene tool making man's presence in Europe. Subsequently over the years a large number of Palaeolithic sites were discovered almost every part of India.

The Peninsular India forms one of the three major geographical regions of the Indian subcontinent. This continental shield lies south of the Indo-Gangetic plains. Broadly the region falls within the tropical and sub-tropical belts with a predominantly monsoonal climate but each of the sub-units are different with its own characteristic features. Indian Palaeolithic sequence is represented by four major divisions: the Lower Palaeolithic, the Middle Palaeolithic, the Upper Palaeolithic and the Mesolithic.

\section{The Ghataprabha Basin}

The pioneer work in the Prehistoric Archaeology of Ghataprabha basin was done by Robert Bruce Foote (1876) with the discovery of fossil remains of rhinoceros (Rhinoceros deccanesis) in the alluvial deposits near Gokak in Belgaum district. The discovery established the existence of quaternary formations in the Ghtaprabha basin.

The Ghataprabha basin is covered with three major geological formations, the Archaeans, the Deccan traps and the Kaladgis. This basin (Latitudes $15^{\circ} 39^{\prime} \mathrm{N}$ and $16^{\circ} 30^{\prime} \mathrm{N}$ and the Longitudes $74^{\circ} \mathrm{E}$ and $76^{\circ}$ E) covers an area of about 7231.15 sq km (Fig.1). Geographically the Kaladgi basin forms south-central part of the Indian Peninsula. It is drained by two major rivers namely the Malaprabha and the Ghataprabha and their tributaries. Physiographically the basin can be divided into three relief units namely, the western hilly tracts, central valley with isolated hills and almost plain area in the lower reaches.

The river Ghataprabha, the eastward flowing river, is one of the southern tributaries of the Krishna in its upper reaches. The catchment of the sub-basin lies approximately between the northern latitudes $15^{\circ} 45^{\prime}$ and $16^{\circ} 25^{\prime}$ and eastern longitudes $74^{\circ} 00^{\prime}$ and $75^{\circ} 55^{\prime}$. It rises from the Western Ghats in Maharashtra at an altitude of $884 \mathrm{~ms}$, flows eastward for $60 \mathrm{kms}$ through the Sindhudurg and Kolhapur districts of Maharashtra, forms the border between Maharashtra and Karnataka for $8 \mathrm{kms}$ and then enters Karnataka. In Karnataka, the river flows for 216 kms through 
Belgaum district and meets the river Krishna near Bagalkot. It gives rise to the well-known Gokak Falls. After a run of $283 \mathrm{kms}$, the river joins the Krishna on the right bank at Kudalasangama at an elevation of $500 \mathrm{~ms}$, about $16 \mathrm{kms}$ from Almatti. The principal tributaries are the Tamraparni, the Hiranyakeshi and the Markandeya. In the source, the river Ghataprabha and its tributaries are characterized by youthful features such as potholes, knick points in the form of waterfalls, the dominance of boulders and cobbles in the modern as well as in the old river beds. In further advance, the valleys are relatively broad and well developed flood plains. In the lower reaches its fully mature stream characteristics are visible. The braiding of the river is another characteristics observed.

\section{A Review on Palaeolithic Cultures in the Ghataprabha Basin}

On the strong foundation laid by Foote on prehistoric archaeology in this region, investigations of Palaeolithic archaeology in Karnataka, began in full swing after the 1950s. Joshi (1955) carried out geoarchaeological studies in Malaprabha river valley. Sankalia reported the Middle Palaeolithic tools from Bagalkot, Anagwadi and Herekal in the Ghataprabha basin (IAR 1955-56). Banerjee (1957) made a detailed typo-technological analysis of the artifacts collected from Bagalkot, Herekal, Kadampur and Anagwadi sites. Numbers of the Lower and the Middle Palaeolithic sites were identified by Pappu (1974) in the upper Krishna basin and the lower reaches of Ghataprabha River. He studied the Quaternary geomorphology and carried out excavations at Angawadi and Kovalli sites. Later a detailed geoarcaheological investigation was carried out by Pappu and Rajaguru in 1979, 1984, and 1990. This work provided ample evidence for a continuous cultural developments from Lower Palaeolithic to Mesolithic times in the form of a few primary stratified sites, a number of secondary stratified and primary surface sites located on the pediment surface and also factory sites. The detailed geomorphic study of the Palaeolithic settlement in this region was carried by Deo (1991) to understand man-land relationship in prehistoric times. Deo (1991), and Pappu and Deo (1994) applied various morphometric 
parameters such as basin morphometry, slope analysis, relative relief, drainage density etc. to understand the palaeolandscape of the Ghataprabha basin. These studies reveal that the Palaeolithic cultures in the Ghataprabha basin have continuous cultural succession from the Lower Palaeolithic to the Upper Palaeolithic in different parts of the basin. About 119 sites yielding artefacts of Lower, Middle and Upper Palaeolithic tools have been recognized (Fig.2). These sites of different phases occur in varied ecological situations such as alluvial or channel gravel sites, high level gravel sites, pediment surface sites, factory sites and river bed sites. Majority of these are situated on the riverine environment and are concentrated in the lower reaches of the basin. The Lower Palaeolithic sites like Anagwadi and Katari have preserved evidence in a relatively primary context. The sites are also situated in the areas where required raw material is found in abundance (Pappu and Deo 1996).

Table 1. Palaeolithic Site Distribution in the Ghataprabha Basin

\begin{tabular}{|l|c|c|c|}
\hline & $\begin{array}{c}\text { Upper } \\
\text { reaches }\end{array}$ & $\begin{array}{c}\text { Middle } \\
\text { reaches }\end{array}$ & $\begin{array}{c}\text { Lower } \\
\text { reaches }\end{array}$ \\
\hline Lower Palaeolithic & 11 & 9 & 27 \\
\hline Middle Palaeolithic & 15 & 29 & 73 \\
\hline Upper Palaeolithic & -- & 17 & 24 \\
\hline
\end{tabular}

\section{The Site Kovalli: The Nature and its Location in the Landscape}

The Middle Palaeolithic culture has been widely distributed in the Ghataprabha basin, obtained from 113 sites. The majority of the sites are concentrated in the middle and lower reaches of the river Ghataprabha and the assemblage is comprised of scrapers of various types, points, borers and scraper cum borer and borer cum points. There is a change in raw material type during this phase. The main raw material chosen for Middle Palaeolithic artefacts was chert. It is cryptocrystalline variety of silica, associated with limestone. Some important Middle Palaeolithic sites are Katarki, Yadwad, Bevinmatti and Khajjidoni.

The evidence of the Upper Palaeolithic comes from 44 sites and these were also found mostly in middle and lower reaches of the 
Ghataprabha basin, thus forming a cluster of Palaeolithic sites. The Upper Palaeolithic tool kit is made of up scrapers, scrapers, points, borers and knives made either on blades or flake-blades. Chert continues as main raw material, same as that of Middle Palaeolithic. The site of Yadwad and Kovalli are the two type-sites of the Upper Palaeolithic in the Ghataprabha basin.

The place Kovalli lies at a distance of $5 \mathrm{~km}$ north of proper village Kovalli, in Bilgitaluka and at a distance of $21 \mathrm{kms}$ northwest of Bagalkot, Karnataka (Fig.3). The site is situated on the left bank of the Ghataprabha River, about $4 \mathrm{kms}$ away from the present river channel and is surrounded by hills of Kaladgi range, made up of quartzites and limestones. Geologically, Kovalli is situated in the region designed by Foote as "subordinate limestone basin within the limits of greater Kaladgi basin" (Pappu, 1966). The limestone and associated cherts occur in abundance in the surrounding region of Kovalli. There are two localities that have yielded evidence of Palaeolithic arte-facts. Kovalli Hill and Kovalli, these are the two localities that are separated by $7 \mathrm{kms}$ distance. The Kovalli Hill site has yielded Lower Palaeolithic artefacts (Pappu 1966). And the Kovalli site has yielded Middle and Upper Palaeolithic artefacts. The present study is focused mainly on Kovalli site.

The Kovalli Hill site lies on a pediment surface of a quartzite hill slope. Artefactare found in a colluvium of quartzite. This colluviums is very angular. The shape and size of these colluviums is varied. This weathered material has been used for making Lower Palaeolithic arte-facts. The area, approximately $4 \mathrm{~km}$, between the Anagwadinala and Kovalli village, is covered with deep black soil. This area is under cultivation today. Then there is a sudden change in the colour and texture of the soil as one approaches the Kovalli site. The colour changes from black to red and the texture become sandy and there is a huge accumulation of debris of various sizes in the fields and everywhere this debris are under laid by red soil. The red soil appears to be of recent origin, mostly derived from ferruginous limestone. 


\section{Artefact Context}

The site Kovalli has served an ideal site for the Middle Stone Age man in the point of view of his needs i.e., the chert, the main raw material required for making his tools. These people would go in search for such places where readymade raw material of desired size and shape is available in abundance. The tools of the middle and Late Stone Age industries are found in large numbers at this site. Besides regular finished tools, there are unfinished tools in abundance which represent different stages in the process of manufacture of tools from a flake, a core or nodule. In addition to cores and flakes, there are innumerable chips present which have been produced during the actual manufacture of tools. Taking all these factors into consideration, Pappu and Deo (1994) categorised the Kovalli site to be a primary site which has served as a factory site for both of the Middle and Late Stone Age because of the ready availability of preferred raw material. Factory sites are essentially surface sites where cultural material is found on the surface. They are relatively undisturbed and without direct geological context and are called as open air occupation cum factory sites (Deo 1991).

\section{The Site Kovalli: A Revisit}

A survey was carried out recently to understand the geomorphic context of Palaeolithic artefacts at and around Kovalli site. During survey collection of artefacts were made at one of the cherty outcrops in the site (Fig 4.). This shows a convincing evidence of human working area. Some area adjacent to this region is under cultivation. The area has red soil and has a flat surface. Here a new canal has been constructed for the irrigation in the same vicinity. As this canal goes through the site, it is destroying the site. It exposes hundreds of artefacts. A large number of flakes, blades, nodules, cores are concentrated in this region. This locality was tested by a small gird of $1 \times 1$ meter to study the nature of tools types embedded on the surface. The grid was prepared at an altitude of $522 \mathrm{~ms}$, at a place (GPS 16 $16.34^{\prime} \mathrm{N} 75^{\circ} 35.180^{\prime} \mathrm{E}$ ).

A total of 421 artefacts were collected from the surface at Kovalli site. The assemblage comprised of varied types of artefacts. These are classified as worked nodules, flakes, chips, scrapers of various 
types, size and shapes of these major types, a few micro blades, macro blades, naturally backed knives and a single backed blade also present in the collected assemblage. Majority of these artefact(239) (Table 2.) are flake-based and the rest are core-based (182).

Table 2. Classification of artefacts at Kovalli

\begin{tabular}{|c|c|}
\hline Types & Total \\
\hline Worked nodule & 116 \\
\hline Scrapers & 87 \\
\hline Chip & 63 \\
\hline Fake & 35 \\
\hline Core & 18 \\
\hline NBK & 16 \\
\hline Nodule & 13 \\
\hline Point & 11 \\
\hline Micro blade & 10 \\
\hline Macro blade & 10 \\
\hline Borrer & 10 \\
\hline Blade core & 8 \\
\hline Backed knives & 7 \\
\hline elongated parallel side edge flake & 6 \\
\hline Chopper & 5 \\
\hline Burin & 4 \\
\hline Notch & 2 \\
\hline Total & 421 \\
\hline
\end{tabular}

Frequency distribution of artefact types (Fig.1) shows that the assemblage is dominated by worked nodules $(29 \%)$ followed by scrapers (21\%) and chips (11\%).

As the site of Kovalli is in the vicinity of the chert outcrop, 95\% artefacts are made on chert. The other raw material used is quartzite and sandstone (Fig.2). 


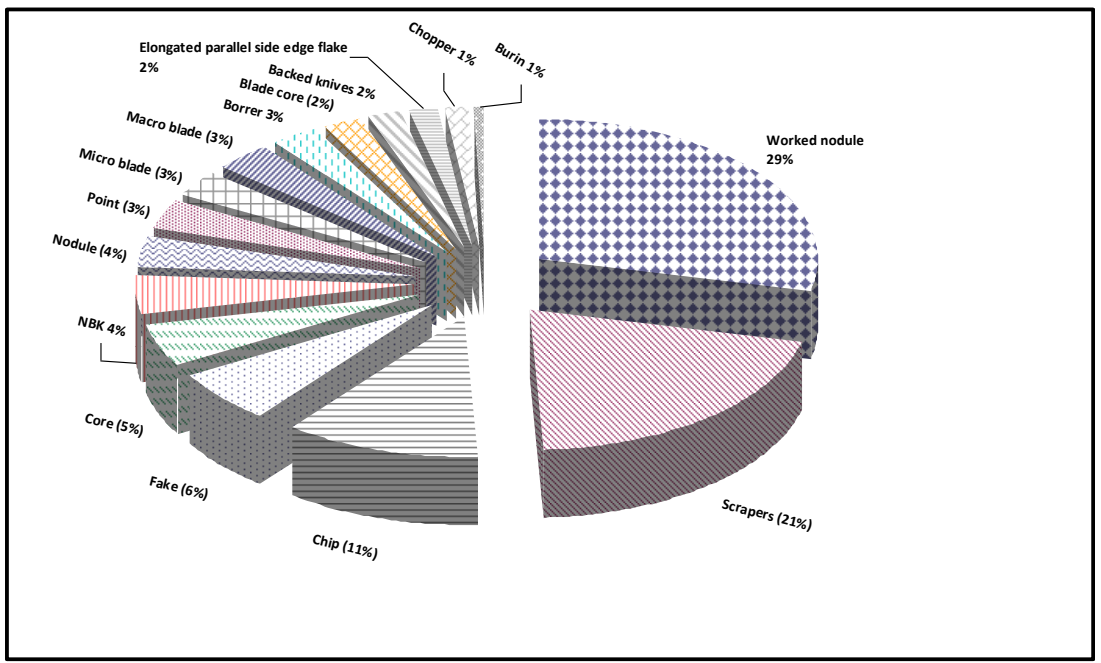

Fig.1. Frequency Distribution of Artefact Types at Kovalli

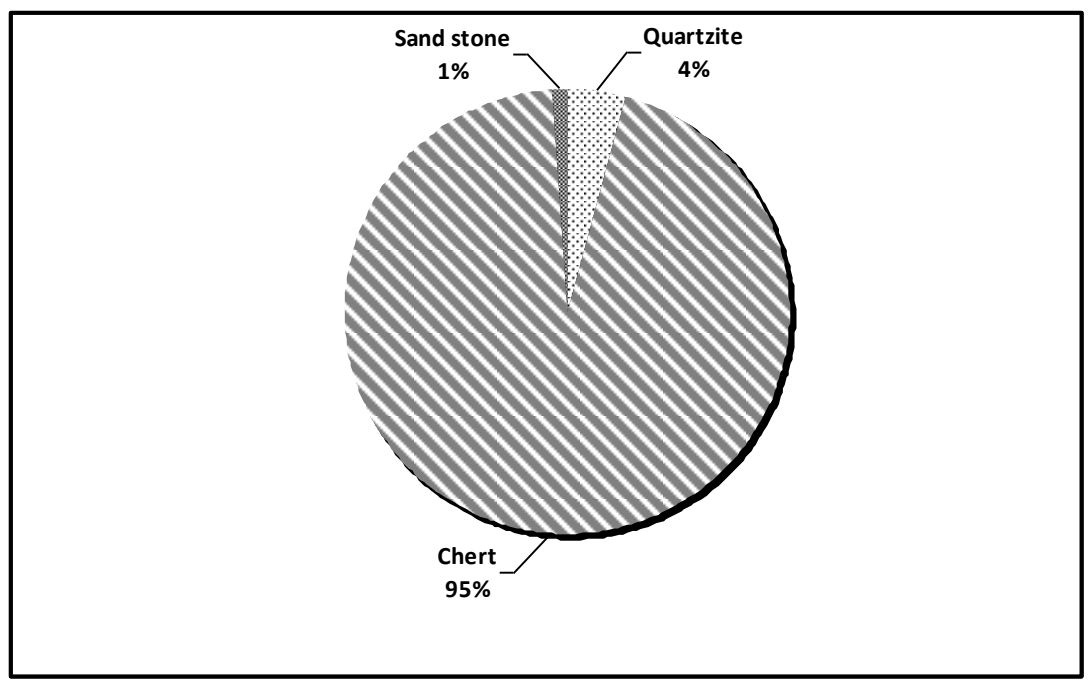

Fig. 2. Raw Material Utilization at Kovalli

\section{Flakes and Chips}

Cortical flakes dominate at Kovalli. Maximum number of flakes (19) have less than $25 \%$ cortex, 12 flakes have 25 to $50 \%$ cortex and only 4 flakes have more than $50 \%$ cortex. Flakes are range from 
initial core preparation, secondary flakes and debitage flakes. Chips are part of debitage, resulting from the retouching and shaping of the tools. The average dimension for flakes is $41.92 \times 31.45 \times 15.10$ $\mathrm{mm}$. Length-wise frequency distribution of flakes shows that majority of the flakes $(88 \%)$ are having less than $3 \mathrm{~cm}$ length and rest are with more than $3 \mathrm{~cm}$ length.

\section{Finished Tools}

A total of 168 finished tools were reported from the Kovalli assemblage. Majority (83\%) of them is flake-based and rests $(17 \%)$ are core-based. Largest numbers of finished tools are made on chert $(96 \%)$ and other raw material (sandstone and quartzite) is represented by $4 \%$ only. Scrapers dominated the finished tool category by contributing $52 \%$ and rest of the assemblage consist of varieties of blades, burin, notch, chopper, point, NBK

\section{NBK- Naturally Backed Knife}

Naturally Backed Knife (henceforth NBK) based on Bordes' typology, following detailed analysis of finished tools from Kovalli assemblage. We are reclassifying some of the finished tools as Bordes (1961) defined NBK as an un-retouched flake or blade that have a sharp cutting edge on one margin and a natural cortical surface (the "back") on the opposite edge which is perpendicular to nearly or so to the interior surface. It has natural cortex on the backside and the cutting edge is in a convex shape and backing is concave.

There are two sub-types of NBK namely typical and atypical type. Typical naturally backed knife has the cortex on its back. On the other hand, if the back is non-cortical (i.e., plain, broken or formed by flake scars produced before the blank was removed), then it is a typical naturally backed knife. However, according to Bordes in the case of atypical form, traces of "unitization" are mandatory.

In the Kovalli assemblage, a total of sixteen are NBK types that were classified as elongated flakes or blade-flakes in earlier classifications. Out of these only one is classified as typical NBK and fifteen artefacts can be classified as atypical NBK (Fig 7). Cross- 
section analysis of atypical NBK shows that four NBKs are having trapezium (Figs. 7a, 8a) and eight with scalene and triangular shape (Figs $7 b, c, d, e, 8 b, c$, and d). Out of fifteen atypical NBK, five artefacts are with dorsal surface having single straight ridge without any other flake scars (Fig 7b). The shape of backing side of these five NBKs is straight. Observations on the cutting edge of these artefacts show that they are either concave or straight in shape. One of the NBKs (Figs. 7e, 8b) has the unique feature of thickness reduction sequence. This is evidenced by the negative flake scar from backing side towards the direction of the cutting edge, resulting from pre-blank detachment. There are seven artefacts (Figs. 7c, 8d) with multiple negative flake scars having multidirectional on the dorsal surface which is a phenomenon of pre-detachment of the NBK.

Reduction sequence of an atypical NBK from Kovalli shows that the core is prepared with an average platform angle of $103^{\circ}$. These NBKs are having an average of $70^{\circ}$ backing angle and $38^{\circ}$ of cutting edge angle (Table 3).

Table 3. Various Angles of a Typical NBK from Kovalli

\begin{tabular}{|l|c|c|c|c|}
\hline \multicolumn{5}{|c|}{ NBK- Atypical } \\
\hline & $\begin{array}{c}\text { Cutting } \\
\text { edge angle }\end{array}$ & $\begin{array}{c}\text { Backing } \\
\text { angle }\end{array}$ & $\begin{array}{c}\text { Platform } \\
\text { angle }\end{array}$ & $\begin{array}{c}\text { Ridge } \\
\text { angle }\end{array}$ \\
\hline Average & $38^{0}$ & $70^{0}$ & $103^{0}$ & $89^{0}$ \\
\hline Maximum & $48^{0}$ & $82^{0}$ & $115^{0}$ & $104^{0}$ \\
\hline Minimum & 290 & $40^{0}$ & $75^{0}$ & $65^{0}$ \\
\hline
\end{tabular}

Other than NBK, there are seven artefact classified as backed knives that also belong to the elongated flake technology. However, the difference between the NBK and backed knife is that the backed knife has the deliberate retouching after blank removal to create backing on one of the side opposite to the cutting edge side. These backed knives have unidirectional and discontinued backing pattern. 


\section{Discussion and Summary}

The site Kovalli is known as a type site for Middle Palaeolithic culture since its discovery. It is reported as an extensive workshop that came up on raw material source (Pappu 1974, Pappu and Deo 1994, Paddayya 2011). These artefacts are exposed recently and found on the surface.

The Kovalli artefacts are classified as core-based and flake-based. Flake-based arte-fact assemblages generally characterize the Middle Palaeolithic of the Indian subcontinent (Jayswal 1978, Paddayya 1984). On the other hand core-based assemblages are found to have similar characters with European Middle Palaeolithic. However, James and Petragliya (2005) pointed out that core-based artefacts are not corresponding with the European counterparts as they are yet to be supported by detailed typological studies. Variation in the presence or absence of different tool types and their relative frequencies is observed in the South Asian Middle Palaeolithic assemblage composition (James 2003). The general pattern throughout the Indian subcontinent (James and Petraglyia 2005) shows scraper is the dominant tool type. On the other hand points are much less common in north-western and north-central regions than they are in the southeast. Further, they claimed that tool types identified as "knives" and "borers" are rare in Indian Middle Palaeolithic assemblages. However, such geographical patterning is not observed at many sites. The tool types, knives and borers are present in the Kovalli assemblage. Such variation in the occurrence of these rarer tool forms at some sites can be explained by chronological change.

Petraglyia et al. (2003) have reported early Middle Palaeolithic overlying the Late Acheulian in the Kaladgi basin, Karnataka. Paddayya (1984) stated that presence of diminutive handaxe is the feature of early Middle Palaeolithic. On the other hand Sali (1989) has classified Middle Palaeolithic at the site of Patne with a stage of "advanced" Middle Palaeolithic. Pal (2001) divided the Middle Palaeolithic culture in at least three developmental phases

i) the early Middle Palaeolithic with the artefacts of the Acheulian tradition, 
ii) ii) middle Middle Palaeolithic with artefacts made on flakes detached from prepared core and discoidal cores and

iii) iii) late Middle Palaeolithic with a blade element in the artefact assemblage.

The present re-examination of the Kovalli assemblage shows the following main features:

In general, the assemblage is dominated by flake-based artefact (57\%). However, core-based artefacts (43\%) also have sizable contribution in the assemblage. There are no artefacts of the Acheulian tradition at Kovall site. It is important to note that the Lavallois technique is not represented in the Kovalli assemblage. Amongst the shaped tools, scrapers are the most numerous. Although other types (points, borer, burins, and knives) are also present with less percentage. A reclassification of the assemblage resulted in identifying a new type of shaped tool called NBK where cortex was not removed since cortical laminar items were a desired end- product as reported by Barkai et al. (2006) from Qesem Cave assemblage in Israel.

Based on these observations we suggest that the Kovalli assemblage can be categorized as a mixture of middle Middle Palaeolithic and late Middle Palaeolithic as per Pal's (2001) classification. And it can be categorized as "advanced" Middle Palaeolithic as per Petraglyia et al. (2003).

\section{Acknowledgements}

This paper is based on dissertation submitted by Sony J Mathew (2012) to Deccan College, Deemed to be University, Pune as partial fulfilment of MA in AIHC and Archaeology. We acknowledge the help of Sheila Mishra and Yogesh M in the analysis of stone tools and villagers of Kovalli for their warm support during our field work. We acknowledge the help given by S N Rajaguru for his valuable help in Geoarchaeolgy. Special thanks are due to DD Phule, Deccan College, for drawing of the artefacts. 


\section{References}

Banerjee, K. D. (1957). Middle palaeolithic industries of the deccan. Unpublished PhD Thesis, University of Pune.

Barkai, R. A., Gopher,. \& Ron, S. (2006). Middle pleistocene blade production in the levant: An amudian assemblage from Qesem cave. Israel. Eurasian Prehistory, 3(2), 39-74.

Foote, R. B. (1876). The Geological features of the south Maratha country and adjacent districts. In Memories of Geological Survey of India 12(1).

Ghosh, A. K. (1972). Flake and flake-blade industries in India in the context of human evolution. In B A K F (Ed.), The Origin of Homosapiens (pp. 95-100).

H.V.A. James \& M. D. Petraglia. (2005).Modern human origins and the evolution and behaviour in the later pleistocene record of South Asia. Current Anthropology. 46. Supplement: S1-S27Indian archaeology: A review, 1955-56. p.5, New Delhi: Archaeological Survey of India.

Misra, V. N. (1962). Problems of terminology in Indian Prehistory, The Eastern Anthropologist 15 (2). Pp 113-24.

Paddayya, K. (1984). India. neue forschungen zur-Altsteinzeit. O. Bar-Yosef, (Ed.), pp. 345-403.Munchen: Verlag C. H. Beck.

Paddayya, K.(2008). Palaeolithic cultures in encyclopaedia of archaeology. Vol. 1. Deborah M. P. (Eds.) pp. 768-791. Oxford. Elsevier \& Academic Press.

Paddayya, K.(2011). Stone age technology in India. Ancient India 1: pp 968.

Pal, J. N. (2002). The Middle palaeolithic culture of South Asia in (Indian Archaeology in Retrospect. (1): Prehistory. Korisetter \& S. Setter (Eds.)). pp 67-83. New Delhi. Manohar Publishers.

Pappu, R. S. \& Deo, S. (1994). Man-land relationship during palaeolithic times in the kaladgi basin- Karnataka. Pune. Deccan College

Pappu, R. S. (1974). Pleistocene studies in the upper krishna basin. Pune. Deccan College.

Rama Rao, B.(1961). A Handbook of geology of Mysore State. Bangalore: Bangalore printing and publishing company.

Sankalia, H. D. (1964).Middle stone age cultures in India and Pakistan. Science. 146. pp. 365-375.

Sushama, G. D. (1991). Geomorphic Study of the Palaeolithic Settlement in the Ghattaprabha basin, Karnataka. Unpublished PhD Thesis. University of Pune. 


\section{Appendix}

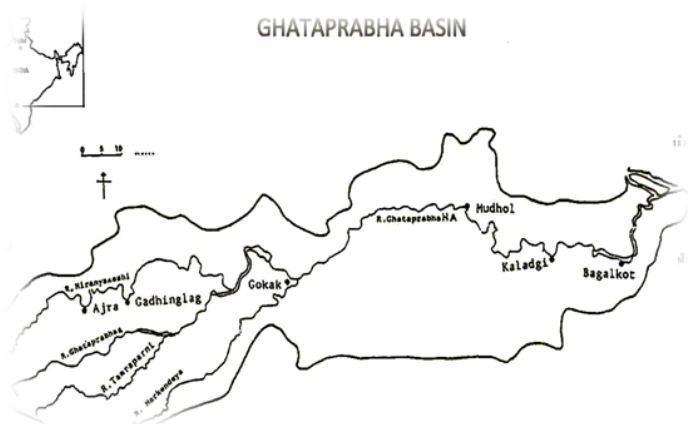

Fig. 3. Map showing the Ghataprabha basin (after Deo 1991)

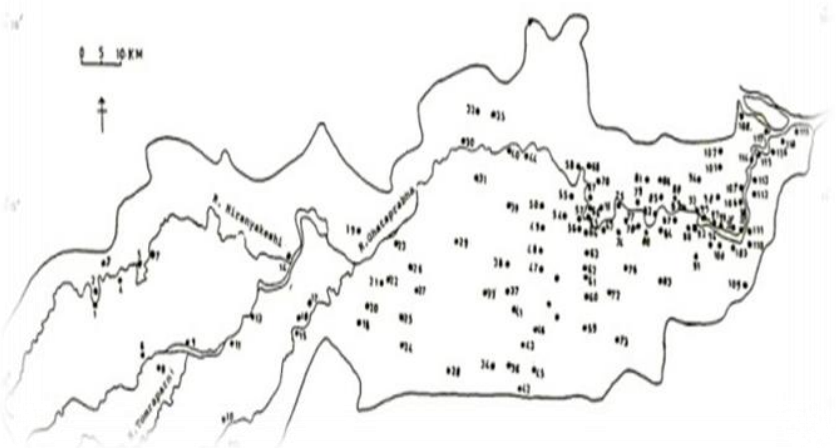

Fig. 4. Map Showing the Distribution of the Palaeolithic Sites in the Ghataprabha Basin (After Deo 1991) 


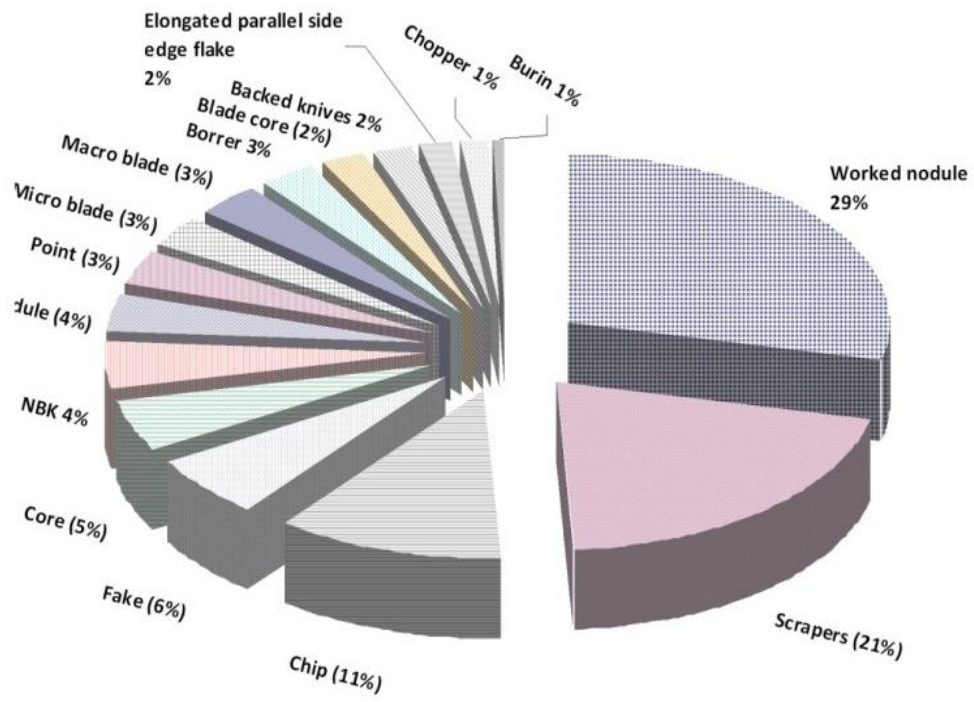

Fig. 5. Location of Kovalli Hill Site and the Site Kovalli
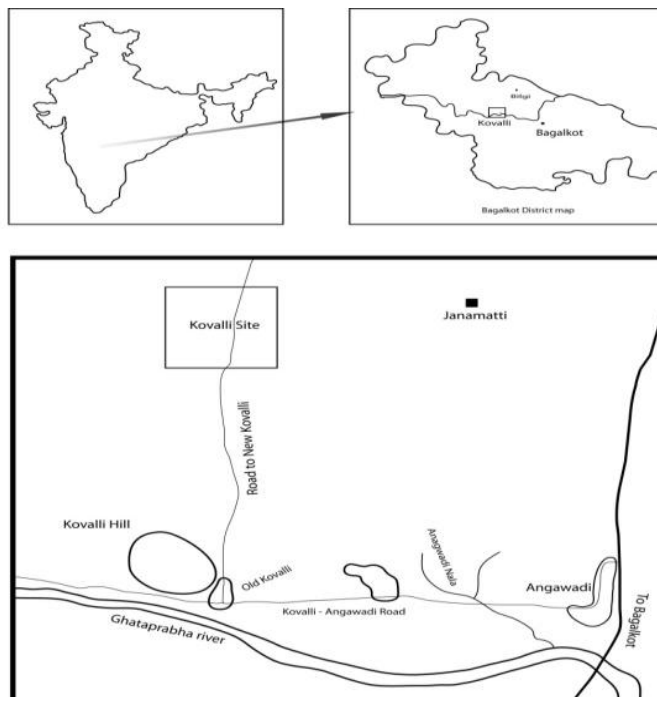

Fig. 6 Chert Outcrops at Kovalli 


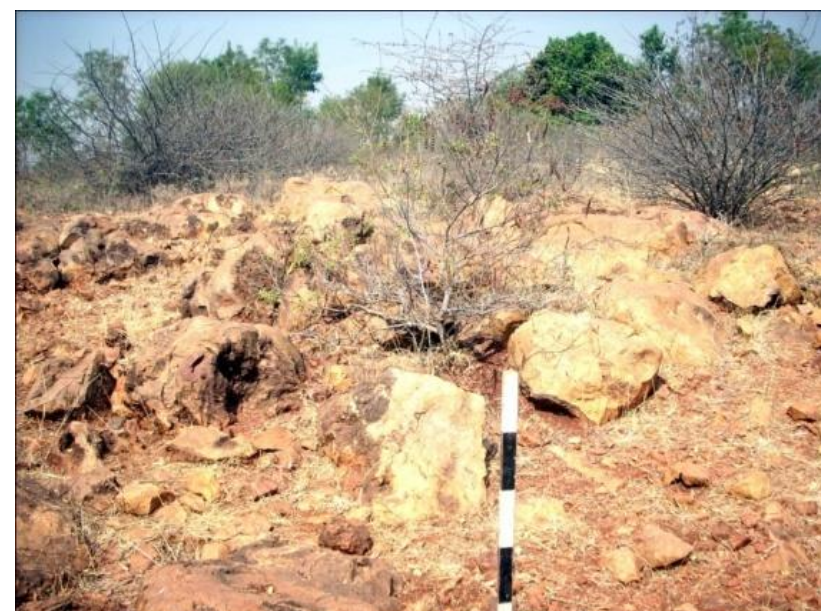

Fig. 7. Frequency Distribution of Artefact Types at Kovalli

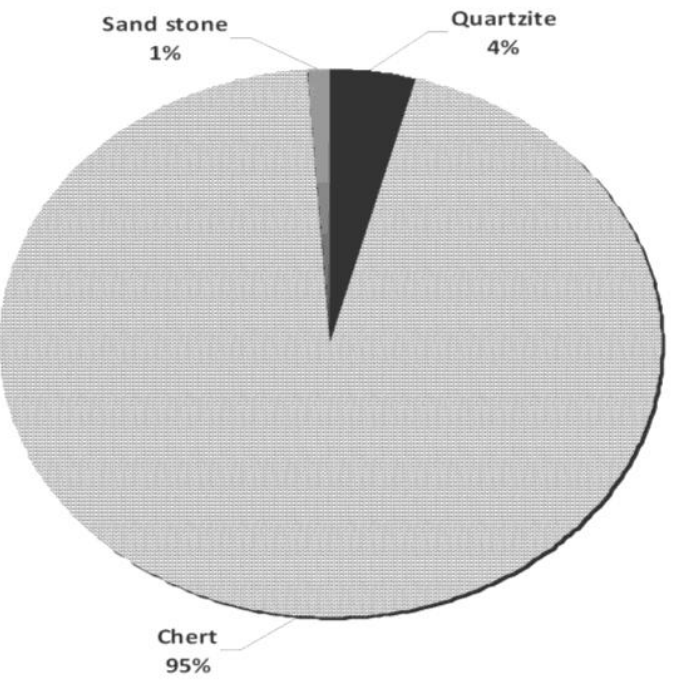

Fig. 8. Raw Material Utilization at Kovalli 


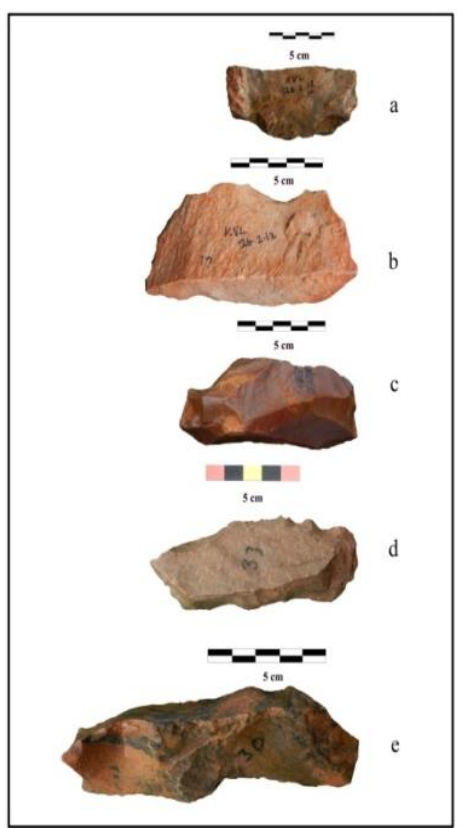

Fig. 9. Types of NBK at Kovalli

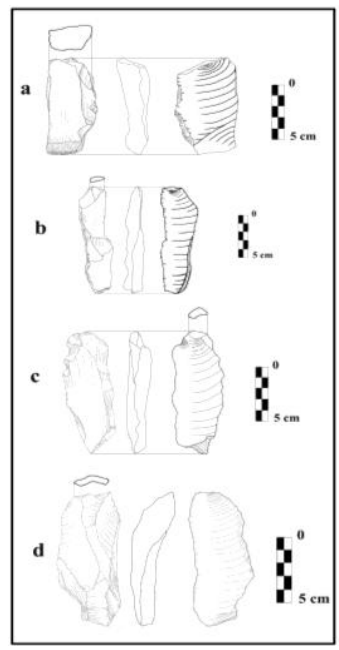

Fig. 10. Illustrations of Representative NBK at Kovalli 